J. Clin. Chem. Clin. Biochem.

Vol. 19, 1981, pp. 339-345

\title{
Comparison of Serum $\beta 2$-Microglobulin and Carcinoembryonic Antigen (CEA) in the Follow-Up of Breast Cancer Patients
}

\author{
By H.J. Staab
}

Friedrich-Miescher-Laboratorium der Max-Planck-Gesellschaft, Tübingen,

\section{M. Ahlemann}

Strahleninstitut der Universität Tübingen,

\section{F. A. Anderer}

Friedrich-Miescher-Laboratorium der Max-Planck-Gesellschaft, Tübingen,

K. Hiesche and W. Rodatz

Pharmacia Diagnostics AB, Uppsala, Schweden

(Received September 6/December 4, 1980)

Summary: Using commercially available radioimmune test kits, serial determinations of serum $\beta 2$-microglobulin and CEA were performed in 337 patients, who had been treated for breast cancer by modified radical mastectomy and radiotherapy. The pre-therapeutic data indicated a higher incidence of pathological $\beta 2$-microglobulin and CEA levels in patients with distant metastases than in patients with localized disease. However, this finding did not allow the conclusion of a direct complementarity of $\beta 2$-microglobulin and CEA as tumour markers, since the group of patients with distant metastasis contained a high percentage of elderly patients who generally can be expected to have elevated $\beta 2$-microglobulin serum concentrations. Therefore, the correlation of the clinical course of malignant disease and the incidence of relapses with the changes of serum $\beta 2$-microglobulin and CEA concentrations was examined during the post-treatment surveillance: $7 / 9$ cases $(78 \%)$ with local recurrence and $46 / 73$ cases $(63 \%)$ with distant spread of disease were not indicated in the $\beta 2$-microglobulin follow-up by pathologic serum concentrations, whereas in the CEA follow-up only $1 / 9$ and $2 / 73$ false negative indications were registered. The poor correlation suggests that serum $\beta 2$-microglobulin is not directly tumour associated in breast cancer and does not fulfill the criteria of a tumour marker.

\section{Vergleich von Serum $\beta 2$-Mikroglobulin und CEA in der klinischen Überwachung von Patienten mit Brustkrebs}

Zusammenfassung: Routine-Bestimmungen von $\beta 2$-Mikroglobulin und CEA im Serum wurden bei 337 Patienten mit Brustkrebs unter Benützung kommerziell verfügbarer radioimmunologischer Tests durchgeführt. Alle Patienten wurden nach modifizierter radikaler Mastektomie und anschließender Radiotherapie weiter überwacht. Prätherapeutisch wurden im Serum Konzentrationen von $\beta 2$-Mikroglobulin und CEA im pathologischen Bereich wesentlich häufiger bei Patienten mit Fernmetastasen beobachtet als bei Patienten mit lokalisiertem Tumorwachstum. Dieser Befund ließ jedoch keinen direkten Rückschluß auf die Komplementarität von $\beta 2$-Mikroglobulin und CEA als Tumormarker zu, da die Patientengruppe mit Fernmetastasen einen hohen Prozentsatz von älteren Patienten enthielt, bei denen allgemein eine erhöhte $\beta 2$-Mikroglobulin Serumkonzentration zu erwarten war. In der weiteren Überwachung wurde daher die Korrelation des klinischen Verlaufs, insbesondere die Bildung von Rezidiven, mit zeitlichen Veränderungen der $\beta 2$-Mikroglobulin- und CEA-Konzentrationen im Serum überprüft: 7/9 Fällen (78\%) mit Lokalrezidiven und 46/73 Fällen (63\%) mit Fernmetastasen wurden in der $\beta 2$-Mikroglobulin-Überwachung nicht durch pathologische Konzentrationen im Serum angezeigt, während in der CEA.Uberwachung nur $1 / 9$ und 2/73 falsch-negative. Fälle registriert wurden. Die geringe Korrelation weist darauf hin, daß $\beta 2$-Mikroglobulin im Serum in Brustkrebspatienten nicht direkt mit Tumorwachstum assoziiert sein kann und die Kriterien eines Tumor-Markers nicht erfült. 


\section{Introduction}

Highly specific circulating tumour markers in sera of patients with malignant clinical disorders are expected to facilitate the management and postoperative surveillance of cancer patients. In the management of breast cancer patients a tumour marker of unique clinical value has not yet been established. Carcinoembryonic antigen (CEA) (1), an important parameter for disease progression as well as for the early detection of disease recurrence in gastrointestinal cancer (2-13), is of less clinical significance in breast cancer, since patho! ogically elevated serum levels of CEA were recorded in only about $50 \%$ of cases $(14,15)$. Therefore, the development of further diagnostic parameters is of urgent necessity in order to establish methods for a direct surveillance of tủmour growth and control of the efficacy of therapeutic efforts.

In recent years $\beta 2$-microglobulin, the low molecular weight component of the histocompatibility antigens (16), has attracted considerable attention as a possible tumour marker candidate. In a variety of malignant disorders including carcinomas and lymphoid tumours an elevated $\beta 2$-microglobulin serum level was recorded (17-26). However, the significance of these findings siill remains questionable in view of the paucity of data relating the clinical course of malignant disease with the changes in the serum $\beta 2$-microglobulin level. Therefore, in the present investigations special emphasis has been put on the establishment of such a relationship, in order to further characterize the possible role of $\beta 2$-microglobulin as a tumour marker. The study was performed with breast cancer patients who were treated by modified radical mastectomy in various hospitals of our region and were sent to the Medizinische Strahleninstitut in Tübingen for postoperative radiotherapy 4-6 weeks after surgery. For an additional direct comparison with an established tumour marker, parallel determinations of the serum concentration of $\beta 2$-microglobulin and CEA were carried out.

\section{Patients and Methods}

\section{Patients}

337 patients were registered in the study. Their ages varied from 30 to 85 years. All patients had been treated by modified radical mastectomy. The tumour extension was staged by the surgeons according to the clinical criteria (TNM) recommended by the UICC. Information on involvement of axillary lymph nodes was obtained from the pathologist's report.

All patients were thoroughly re-examined before radiotherapy usually 4-6 weeks after mastectomy. The postsurgical treatment of the patients was based on clinical conditions and diagnostic details obtained from chest X-rays, bone and liver scans, compute tomography and routine laboratory tests. Radiation treatment varied with the clinical characteristics and the location of the tumour. Details were given previously (27-28). During the follow-up, patients had routine physical examinations connected with catamnestic investigations and chest $\mathrm{X}$-rays; they underwent other diagnostic methods, when tumour progression or recurrence was suspected.
Blood samples were generally obtained by peripheral venipuncture a few days before radiotherapy, during hospitalization and thereafter during routine clinical visits of the patients.

\section{Methods}

Serum $\beta 2$-microglobulin was analyzed radioimmunologically using the Phadebas- $\beta 2$-microtest (Pharmacia Diagnostics AB, Uppsala, Sweden). The $\beta 2$-microglobulin serum level of healthy persons was reported to range between 0.8 and $2.4 \mathrm{mg} / \mathrm{l}(18,29)$.

Thus, any $\beta 2$-microglobulin serum concentration higher than $2.4 \mathrm{mg} / \mathrm{l}$ in our study was registered as " $\beta 2$-microglobulin positive".

The concentration of CEA in the sera was analyzed after perchloric acid extraction of the sera using the CEA-Roche-RIA test kit (Roche Diagnostics). The CEA serum level of healthy persons did not generally exceed $2.0 \mu \mathrm{g} / 1$ (11). Thus, all CEA serum concentrations above this level were recorded as "CEA positive". This is slightly different from the critical level of CEA determinations of plasma with a value of $2.5 \mu \mathrm{g} / 1$ as recommended by Roche Diagnostics.

\section{Results}

\section{Correlation of preradiotherapeutic $\beta 2$-microglobulin with $C E A$ serum levels}

Preliminary information on the possible role of $\beta 2$-microglobulin as a tumour marker can be obtained from a direct comparison of its serum concentration with that of CEA. The study was performed with sera of breast cancer patients in a blind trial and correlated with age and tumour extension. Preradiotherapeutic serum samples were only available in $163 / 337$ cases. In table 1 the data of $\beta 2$-microglobulin and CEA assays of 163 preradiotherapeutic serum samples are recorded and classified into the following 4 criteria of $C E A / \beta 2$-microglobulin serum levels:

1) samples with neither pathological $\beta 2$-microglobulin nor CEA levels;

2) samples with pathological $\beta 2$-microglobulin but normal CEA levels;

3) samples with normal $\beta 2$-microglobulin and pathological CEA levels;

4) samples with pathological levels of both $\beta 2$-microglobulin and CEA.

These data are listed for 5 age categories and 3 classes of tumour extension.

The patients included in table 1 were selected for radiotherapy, and are therefore not representative for newly diagnosed breast cancer patients. The total percentage of patients with pathological CEA concentrations was $67 \%$ compared with that of patients with pathological $\beta 2$ microglobulin concentration (24\%). About $8 \%$ of all patients $(13 / 163)$ in table 1 showed only pathological $\beta 2$-microglobulin levels which might represent a gain in characterization of malignant disease if the $\beta 2$-microglobulin and CEA were complementary markers. For patients with distant metastases already present at mastectomy a significantly higher incidence of pathological levels of both markers was recorded (tab. 1). More 
Tab. 1. Pre-radiotherapeutic serum $\beta$ 2-microglobulin und CEA levels in patients with breast cancer, who had undergone radical mastectomy, correlated with age and tumour extension (TNM-classification) at primary mastectomy. (one patient $=$ one value).

\begin{tabular}{|c|c|c|c|c|c|c|c|c|c|c|}
\hline \multirow[t]{3}{*}{ Specification } & \multirow{2}{*}{\multicolumn{2}{|c|}{ Patients }} & \multicolumn{4}{|c|}{$\begin{array}{l}\text { Samples with } \\
\mu \mathrm{g} / \mathrm{CEA} / \mathrm{mg} / \mathrm{l} \beta 2 \text {-microglobulin }\end{array}$} & \multicolumn{4}{|c|}{$\begin{array}{l}\text { Total samples } \\
\text { with elevated concentration }\end{array}$} \\
\hline & & & $<2 /<2.5$ & $<2 / \geqslant 2.5$ & $>21<2.5$ & $\geqslant 2 / \geqslant 2.5$ & $\beta 2-$ & globulin & CEA & \\
\hline & $\mathrm{n}$ & $\%$ & $n_{1}$ & $n_{2}$ & $n_{3}$ & $n_{4}$ & $n$ & $\%$ & $\mathrm{n}$ & $\%$ \\
\hline $\begin{array}{lr}\text { Age: } & <40 \\
{[a] \quad} & 40-49 \\
50-59 \\
60-69 \\
>70\end{array}$ & $\begin{array}{r}9 \\
30 \\
42 \\
31 \\
51\end{array}$ & $\begin{array}{r}6 \\
18 \\
26 \\
19 \\
31\end{array}$ & $\begin{array}{r}4 \\
7 \\
14 \\
10 \\
6\end{array}$ & $\begin{array}{l}0 \\
1 \\
3 \\
1 \\
8\end{array}$ & $\begin{array}{r}4 \\
22 \\
23 \\
16 \\
18\end{array}$ & $\begin{array}{r}1 \\
0 \\
2 \\
4 \\
19\end{array}$ & $\begin{array}{r}1 \\
1 \\
5 \\
5 \\
27\end{array}$ & $\begin{array}{l}12 \\
16 \\
53\end{array}$ & $\begin{array}{r}5 \\
22 \\
25 \\
20 \\
37\end{array}$ & $\begin{array}{l}55 \\
73 \\
60 \\
65 \\
73\end{array}$ \\
\hline \multicolumn{11}{|c|}{ Tumour extension: } \\
\hline $\begin{array}{l}T \neq 0, \text { No, Mo } \\
T, N \neq 0, M o \\
M=1\end{array}$ & $\begin{array}{l}64 \\
64 \\
35\end{array}$ & $\begin{array}{l}39 \\
39 \\
22\end{array}$ & $\begin{array}{r}20 \\
18 \\
3\end{array}$ & $\begin{array}{l}3 \\
7 \\
3\end{array}$ & $\begin{array}{l}34 \\
33 \\
16\end{array}$ & $\begin{array}{r}7 \\
6 \\
13\end{array}$ & $\begin{array}{l}10 \\
13 \\
16\end{array}$ & $\begin{array}{l}16 \\
20 \\
46\end{array}$ & $\begin{array}{l}41 \\
39 \\
29\end{array}$ & $\begin{array}{l}64 \\
61 \\
83\end{array}$ \\
\hline Total & 163 & 100 & 41 & 13 & 83 & 26 & 39 & 24 & 109 & 67 \\
\hline
\end{tabular}

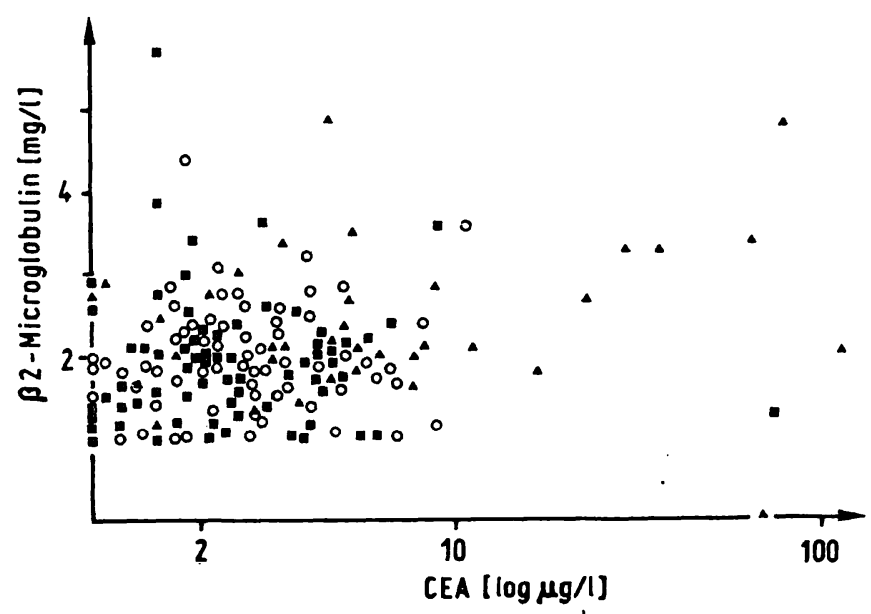

Fig. 1. Semilogarithmic plot of the pre-radiotherapeutic $\beta 2$-microglobulin and CEA serum concentrations of individual patients after modified radical mastectomy followed by radiotherapy. Blood samples were taken 1-4 days before radiotherapy was started. The individual data are specified by the tumour extension (TNM classification: $0=$ patients with $\mathrm{T} 1-4, \mathrm{No}, \mathrm{Mo} ;=$ patients with $\mathrm{T} 1=4$, N1 -3, Mo; $\Delta=$ patients with M1).

detailed information on the possibility of a direct association of $\beta 2$-microglobulin and CEA levels with tumour extension was expected from plotting the preradiotherapeutic serum level of $\beta 2$-microglobulin against the CEA serum concentration for each of 163 patients specified according to the TNM classification recommended by the UICC (fig. 1). No correlation of the individual $\beta 2$-microglobulin concentrations with the pre-therapeutic CEA concentrations is evident. However, in the group of patients with distant metastatic spread and elevated CEA levels $13 / 29$ patients (45\%) have also a $\beta 2$-microglobulin concentration in the pathologic range (tab. $\left.1, n_{2}, n_{3}, n_{4}\right)$. In this subgroup $12 / 13$ patients were older than 70 yearrs and the elevated $\beta 2$-microglobulin levels could also result from the advanced age of the patients, since the data in table 1 demonstrate that the frequency of serum samples with pathological $\beta 2$-microglobulin levels $(\geqslant 2.5 \mathrm{mg} / \mathrm{l})$ increased with advancing age. On the other hand, the CEA serum levels also exhibit an apparent age effect: in the group of patients older than 70 years a distinctly higher percentage of patients with pathological CEA serum concentrations was registered; this could be due to a higher percentage of patients with metastatic breast cancer compared with other age groups.

In table 2 the age effect of the serum levels of both markers within the 3 groups of patients with given tumour extension is listed according to the 4 criteria of CEA/ $\beta 2$-microglobulin serum levels. The number of patients with pathological $\beta 2$-microglobulin levels increases with age in about all subgroups (tab. $2, \mathrm{n}_{2}$ and $n_{4}$ ). For pathological CEA levels (tab. $2, n_{3}+n_{4}$ ) this holds true only for the group of patients with distant metastasis, due to the fact that our patients older than 70 years have a higher incidence of metastasizing tumours (23/51 patients) compared with patients between 60 and 70 years ( $8 / 31$ patients) and patients between 50 and 60 years $(2 / 42)$. On the basis of the results given in table 1 and 2 one cannot entirely exclude an association of the $\beta 2$-microglobulin serum concentration with tumour extension in breast cancer patients. A more detailed characterization of a possible complementarity of $\beta 2$-microglobulin and CEA as tumour markers in breast cancer can be expected from the comparison of the correlation of changes in serum concentration of each marker with the course of malignant disease and disease recurrence.

\section{Correlation of $\beta 2$-microglobulin and CEA levels with the time course of disease}

The possible complementarity of $\beta 2$-microglobulin and CEA as tumour markers in breast cancer was studied by correlating the changes in the serum level of these markers with the clinical course of disease. For this 
Tab. 2. Correlation of age and pre-radiotherapeutic serum $\beta 2$-microglobulin and CEA levels in patients with breast cancer within the given classification of tumour extension (TNM classification).

\begin{tabular}{|c|c|c|c|c|c|c|}
\hline \multirow[t]{3}{*}{ Tumour extension } & \multirow{3}{*}{$\begin{array}{l}\text { Age } \\
\text { [a] }\end{array}$} & \multicolumn{4}{|c|}{ Samples with $\mu \mathrm{g} / \mathrm{l} \mathrm{CEA} / \mathrm{mg} / \mathrm{l} \beta 2$-microglobulin } & \multirow{3}{*}{$\begin{array}{l}\text { Patients } \\
\text { total } \\
\mathrm{n}\end{array}$} \\
\hline & & $<2 /<2.5$ & $<2 / \geqslant 2.5$ & $\geqslant 2 /<2.5$ & $\geqslant 2 / \geqslant 2.5$ & \\
\hline & & $\mathrm{n}_{1}$ & $\mathbf{n}_{2}$ & $\mathrm{n}_{\mathbf{3}}$ & $\mathrm{n}_{\mathbf{4}}$ & \\
\hline$T \neq 0$, No, Mo & $\begin{array}{r}<50 \\
50-59 \\
60-69 \\
\geqslant 70\end{array}$ & $\begin{array}{l}4 \\
9 \\
5 \\
2\end{array}$ & $\begin{array}{l}0 \\
2 \\
1 \\
0\end{array}$ & $\begin{array}{r}14 \\
12 \\
5 \\
3\end{array}$ & $\begin{array}{l}0 \\
1 \\
2 \\
4\end{array}$ & $\begin{array}{r}18 \\
24 \\
13 \\
9\end{array}$ \\
\hline $\mathrm{T}, \mathrm{N} \neq \mathrm{O}, \mathrm{Mo}$ & $\begin{array}{r}<50 \\
50-59 \\
60-69 \\
\geqslant 70\end{array}$ & $\begin{array}{l}7 \\
4 \\
2 \\
5\end{array}$ & $\begin{array}{l}1 \\
2 \\
1 \\
3\end{array}$ & $\begin{array}{r}11 \\
10 \\
7 \\
5\end{array}$ & $\begin{array}{l}0 \\
0 \\
0 \\
6\end{array}$ & $\begin{array}{l}19 \\
16 \\
10 \\
19\end{array}$ \\
\hline$M=1$ & $\begin{array}{r}<50 \\
50-59 \\
60-69 \\
\geqslant 70\end{array}$ & $\begin{array}{l}0 \\
0 \\
1 \\
2\end{array}$ & $\begin{array}{l}0 \\
0 \\
1 \\
2\end{array}$ & $\begin{array}{l}1 \\
2 \\
6 \\
7\end{array}$ & $\begin{array}{r}1 \\
0 \\
0 \\
12\end{array}$ & $\begin{array}{r}2 \\
2 \\
8 \\
23\end{array}$ \\
\hline Total & & 41 & 13 & 83 & 26 & 163 \\
\hline
\end{tabular}

purpose serial determinations of the $\beta 2$-microglobulin and CEA levels were performed during radiotherapy and during the post-treatment surveillance in a selected group of 235 patients.

For the classification of the time courses of $\beta 2$-microglobulin and CEA serum levels we chose 4 categories:

1) increasing concentrations in the pathological range;

2) decreasing from pathological to normal;

3) unchanging in the pathological range (marked with an asterisk in tab. 3);

4) unchanging in the normal range.

The specification of the clinical course of disease was essentially based on the diagnosis of local recurrence and distant metastasis. Suspected recurrences due to various clinical criteria, but still lacking final confirmation, were not recorded as a positive diagnosis of recurrence.

In table 3 the $\beta 2$-microglobulin and CEA time courses are listed in relation to the status of malignant disease. All possible combinations of the $\beta 2$-microglobulin and the CEA time course categories were observed. In $160 / 235$ cases ( $68 \%$ ) $\beta 2$-microglobulin was silent, i.e. the $\beta 2$-microglobulin serum concentration remained in the normal range throughout. Unchanging CEA levels in the normal range were registered only for $87 / 235$ patients (37\%). Excluding all cases with both markers silent, there were only $28 / 235$ cases (12\%) with directly coincident $\beta 2$-microglobulin and CEA time courses.

Our follow-up study has been in progress now for 9-16 months depending on the time of entry of patients. During this time, a local recurrence of disease was detected in 9 patients, and distant metastases in 73 patients. The rate of false negative indications in the $\beta 2$-microglobulin follow-up has been very high: 53/82 cases $(65 \%)$ with local recurrence or distant spread of disease were not indicated, whereas only $3 / 82$ fạlse negative indications (4\%) were recorded in the CEA follow-up.

In some of the 'false CEA positive' cases the pathological CEA serum concentration were due to other nonmalignant disease known to induce increased CEA levels: liver malfunction $(n=1)$, liver cirthosis $(n=2)$, colitis $(n=1)$. One patient with a 'false positive' indication in the $\beta 2$-microglobulin follow-up had an impaired renal function known to be associated with increased $\beta 2$-microglobulin levels $(38,39)$.

\section{Discussion}

Carcinoma cells in culture have been found to produce $\beta 2$-microglobulin at a higher concentration than nonneoplastic cells $(40,41)$. These findings lead to the suggestion that $\beta 2$-microglobulin is a potential tumour marker. The results of our follow-up study of 235 breast cancer patients, who had undergone radical mastectomy and radiotherapy, do not support this suggestion when changes of the $\beta 2$-microglobulin serum levels are correlated with the clinical course of malignant disease. In $53 / 82$ cases $(65 \%)$ with disease recurrence false negative indications of the. $\beta 2$-microglobulin time course were registered. In contrast, the CEA follow-up showed only $3 / 82(4 \%)$ false negative indications. These results correspond to the data of a previous study carried out with patients with carcinomas of the gastrointestinal tract (42).

A distinctly higher percentage of cases with pathological concentrations of $\beta 2$-microglobulin and CEA was recorded in the group of patients older than 70 years when compared with the other age groups (tab. 1 and 2), thus agreeing with previous studies $(26,29,30)$. This observation coincided with a higher frequency of metastatic disease in the elderly patients as compared to the other age groups. In case of $\beta 2$-microglobulin, the 
Tab. 3. Correlation of the changes of $\beta 2$-microglobulin and CEA serum concentrations during and after radiotherapy with the clinical course of malignant disease.

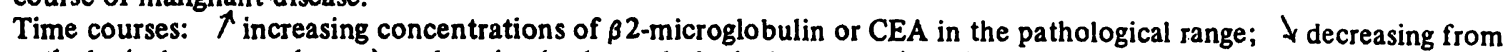
pathological to normal; $* \rightarrow$ unchanging in the pathological range; $\rightarrow$ unchanging in the normal range.

\begin{tabular}{|c|c|c|c|c|c|c|c|c|c|}
\hline \multirow{2}{*}{\multicolumn{2}{|c|}{$\begin{array}{l}\text { Markers } \\
\text { Time course }\end{array}$}} & \multicolumn{3}{|c|}{ Clinical course of disease } & \multirow{3}{*}{$\begin{array}{l}\text { Total } \\
\text { patients }\end{array}$} & \multicolumn{4}{|c|}{ False indications } \\
\hline & & \multirow{2}{*}{$\begin{array}{l}\text { No recurrence } \\
\text { to date }\end{array}$} & \multirow{2}{*}{$\begin{array}{l}\text { Local } \\
\text { recurrence }\end{array}$} & \multirow{2}{*}{$\begin{array}{l}\text { Distant } \\
\text { metastases }\end{array}$} & & \multicolumn{2}{|c|}{ Negative } & \multirow{2}{*}{$\begin{array}{l}\text { Positive } \\
\beta 2- \\
\text { micro- } \\
\text { globulin }\end{array}$} & \multirow[b]{2}{*}{ CEA } \\
\hline $\begin{array}{l}\beta 2- \\
\text { micro- } \\
\text { globulin }\end{array}$ & CEA & & & & & $\begin{array}{l}\beta 2- \\
\text { micro- } \\
\text { globulin }\end{array}$ & CEA & & \\
\hline$\uparrow$ & $\uparrow$ & $\begin{array}{l}3^{\mathrm{a}} \\
1 \text { liver malfunction }\end{array}$ & 0 & $\begin{array}{ll}4 & \text { bone } \\
2 & \text { liver } \\
1 & \text { lung } \\
3 & \text { multiple }\end{array}$ & 14 & - & - & $3^{a}+1$ & $3^{a}+1$ \\
\hline$\downarrow$ & $\uparrow$ & $1^{\mathbf{a}}$ & 1 & $\begin{array}{ll}1 & \text { bone } \\
1 & \text { liver } \\
1 & \text { lung }\end{array}$ & 5 & 4 & - & - & $1^{a}$ \\
\hline$* \rightarrow$ & $\uparrow$ & $1^{2}$ & 1 lymphnode & $\begin{array}{ll}1 & \text { bone } \\
1 & \text { brain } \\
3 & \text { liver } \\
4 & \text { multiple }\end{array}$ & 11 & - & - & $1^{a}$ & $1^{a}$ \\
\hline$\rightarrow$ & $\uparrow$ & $6^{\mathrm{a}}$ & $\begin{array}{l}3 \\
1 \text { lymphnode }\end{array}$ & $\begin{aligned} 12 & \text { bone } \\
1 & \text { brain } \\
7 & \text { liver } \\
6 & \text { lung } \\
3 & \text { multiple }\end{aligned}$ & 39 & 32 & - & - & $6^{a}$ \\
\hline$\uparrow$ & $\downarrow$ & 3 & - & - & 3 & - & 0 & 3 & - \\
\hline$\downarrow$ & $\downarrow$ & 6 & - & - & 6 & 0 & 0 & - & - \\
\hline$* \rightarrow$ & $\downarrow$ & 2 & - & - & 2 & - & 0 & 2 & - \\
\hline$\rightarrow$ & $\downarrow$ & 21 & 1 & - & 22 & 1 & 1 & - & - \\
\hline$\pi$ & $* \rightarrow$ & $2^{a}$ & - & $\begin{array}{ll}1 & \text { brain } \\
2 & \text { liver } \\
1 & \text { lung }\end{array}$ & 6 & - & - & $2^{a}$ & $2^{a}$ \\
\hline$\downarrow$ & $* \rightarrow$ & $1^{a}$ & - & $\begin{array}{ll}1 & \text { bone } \\
1 & \text { liver } \\
1 & \text { lung } \\
1 & \text { multiple }\end{array}$ & 5 & 4 & - & - & $1^{a}$ \\
\hline$* \rightarrow$ & $* \rightarrow$ & $\begin{array}{l}1^{a} \\
3\end{array}$ & 1 & $\begin{array}{l}2 \text { liver } \\
1 \text { multiple }\end{array}$ & 8 & - & - & $1^{a}+3$ & $1^{a}+3$ \\
\hline$\rightarrow$ & $* \rightarrow$ & $\begin{array}{l}1^{\mathrm{a}} \\
13 \\
2 \text { (liver cirrrhosis) } \\
1 \text { (colitis) }\end{array}$ & 1 lymphnode & $\begin{array}{l}5 \text { bone } \\
1 \text { brain } \\
2 \text { lung } \\
1 \text { multiple }\end{array}$ & 27 & 10 & - & - & $1^{a}+16$ \\
\hline$\uparrow$ & $\rightarrow$ & $\begin{array}{l}3 \\
1 \text { (renal disease) }\end{array}$ & - & - & 4 & - & 0 & 4 & - \\
\hline$\downarrow$ & $\Rightarrow$ & 8 & $=$ & - & 8 & 0 & 0 & - & - \\
\hline$* \rightarrow$ & $\rightarrow$ & 3 & $=$ & - & 3 & - & 0 & 3 & - \\
\hline$\Rightarrow$ & $\Rightarrow$ & 70 & - & $\begin{array}{l}1 \text { multiple } \\
1 \text { lung }\end{array}$ & 72 & 2 & 2 & - & - \\
\hline Total & & 153 & 9 & 73 & 235 & 53 & 3 & $7^{a}+16$ & $16^{a}+20$ \\
\hline
\end{tabular}

a recurrence suspected but not yet clinically confirimẹ 
incidence of pathological $\beta 2$-microglobulin levels was two-fold higher in patients with distant metastases than in patients with localized disease. This finding may indicate a direct association of the serum $\beta 2$-microglobulin level with malignant growth. However, a detailed interpretation is complicated due to an age effect $(25,30)$, possibly induced by some clinical conditions associated with advanced age, including renal and immune disorders, known to markedly increase the serum level of $\beta 2$-microglobulin $(19,38,39)$. In contrast, the criteria of CEA as a tumour marker in breast cancer have been fully established in previous investigations $(31,37)$ and the influence of distant spread of disease on the CEA serum concentration regardless of age became evident $(28,27,31-36)$. The high incidence of pathological CEA levels in our group of breast cancer patients as compared with prior studies $(14,15)$ is related to the fact that the present study did not deal with an unselected group of newly diagnosed patients.

The valuation of 'false positive' indications in table 3 is somewhat arbitrary. $7 / 23$ 'false positive' indications in the $\beta 2$-microglobulin follow-up and $16 / 36$ 'false positive' indications in the CEA follow-up are cases where recurrence or metastatic spread is suspected but not yet clinically confirmed. With advancing time of clinical surveillance these numbers in table 3 may change if suspected recurrences are clinically confirmed. In a longer follow-up recurrences might be also expected in the group of 'correct negative cases', but according to our experience these cases have a distinctly lower probability of recurrence of disease (37).

A direct evaluation of $\beta 2$-microglobulin as a tumour marker in breast cancer was made from the correlation with the clinical course of disease and disease recurrence. As shown in table 3 , in the $\beta 2$-microglobulin follow-up, $46 / 73(63 \%)$ cases of metastatic spread and $7 / 9$ cases :(78\%) with local recurrence were not indicated by pathologic $\beta 2$-microglobulin serum concentrations. Therefore, since the clinical course of disease coincided with the changes of $\beta 2$-microglobulin levels only in the minority of cases, $\beta 2$-microglobulin does not appear to fulfill the criteria of a tumour marker in breast cancer. On the basis of these results it is suggested that the changes of $\beta 2$-microglobulin serum levels seen in carcinomas may reflect a biological event, possibly lymphocy te stimulation (22), frequently associated with the malignant growth.

\section{Acknowledgements}

The authors want to thank Ms. S. Glock and Mrs. E. Wehrle for excellent technical assistance.

\section{References}

1. Gold, P. \& Freedman, S. O. (1965), J. Exp. Med. 121, 439462.

2. Booth, S. N., Jamieson, G. C., King, J. P., Leonard, J., Oates, G. D. \& Dykes, P. W. (1974), Br. Med. J. 4, 183-187.

3. Holyoke, E. D., Chu, T. M. \& Murphy, G. P. (1975), Cancer 35, 830-836.

4. Khoo, S. K., Daunter, B. \& Mackay, E. (1979), Internat. J. Gynaecol. Obstet. 16, 388-393.

5. Lo Gerfo, P. \& Herter, F. P. (1975), Ann. Surg. 181, 81-84.

6. Mach, J. P., Jaeger, P. H., Bertolet, M. M., Ruegsegger, C. H., Loosli, R. M. \& Petthavel, J. (1974), Lancet II, 535-540.

7. Mackay, A. M., Patel, S., Carter, S., Stevens, U., Laurence, D. J. R., Cooper, E. H. \& Neville, A. M. (1974), Br. Med. J. 4, 382-385.

8. Martin, E. W., James, K. K., Hurtubise, P. E., Catalano, P. \& Minton, J. P. (1977), Cancer 39, 440-446.

9. Ravry, M., Moertel, C. G., Schutt, A. J. \& Go, V. L. W. (1974), Cancer 34, 1230-1234.

10. Sorokin, J. J., Sugarbaker, P. H., Zamcheck, N., Pisick, M., Kupchick, H. Z. \& Moore, F. D. (1974), J. Am. Med. Ass. 288, 49-53.

11. Staab, H. J., Anderer, F. A., Stumpf, E. \& Fischer, R. (1977), Dtsch. Med. Wochenschr. 102, 1082-1086.

12. Sugarbaker, P. H., Skarin, A. T. \& Zamcheck, N. (1976), J. Surg. Oncol. 8, 523-537.

13. Herrera, M. A., Chu, T. M. \& Holyoke, E. D. (1976), Ann. Surg. 183, 5-9.

14. Laurence, D. J. R. \& Neville, A. M. (1972), Br. J. Cancer $26,335-355$.

15. Lamerz, R. \& Fateh-Moghadam, A. (1975), Klin. Wochenschr 53, 193-203.

16. Peterson, P. A., Cunningham, B. A., Berggard, I. \& Edelman, G. M. (1972), Proc. Natl. Acad. Sci. USA 69, 1697-1701.

17. Cooper, E. H., Bunning, R., Illingworth, S., Späti, B. \& Child, J. A. (1978), Biomedicine 29, 154-15.8

18. Daver, A., Wafflart, J., BenBouali, A., Minier, J. F. \& Larra F. (1978), Phadedoc Diagnostic Commun. 3, 24-30, Pharmacia Diagnostics AB, Uppsala, Sweden.

19. Evrin, P. E. \& Wibell, L. (1973), Clin. Chim. Acta 43, 183186.

20. Fateh-Moghadam, A., Mantel, W., Neumeier, D., Hannig, C., Kristin, H. \& Otte, M. (1978), Klin. Wochenschr. 56, 267270.

21. Kin, K., Sakurabayashi, I. \& Kawai, T. (1977), Gānn 68, $427-343$.

22. Kin, K., Kasahara, T., Itch, Y., Sakurabayashi, I., Kawai, T. \& Morita, M. (1979), Immunology 36, 47-54.

23. Larra, F., Daver, A., Deroche, C. \& Mittler, C. (1978), Excerpta Medica Internat. Congr. Series 439, 490-495.

24. Shuster, J., Gold, P. \& Poulik, M. D. (1976), Clin. Chim. Acta $67,307-313$.

25. Teasdale, C., Mander, A. M., Fifield, R., Keyser, J. W., Newcombe, R. G. \& Hughes, L. E. (1977), Clin. Chim. Acta 78, 135-143.

26. Amlot, P. L. \& Adinolfi, M. (1979), Europ. J. Cancer 15, 791-796.

27. Staab, H. J., Ahlemann, L. M., Koch, H. L. \& Anderer, F. A. (1980), Oncodevelopmental Biology and Medicine 1,151-160.

28. Staab, H. J., Anderer, F. A., Ahlemann, L. M. \& Frommhold, W. (1979), Carcino-Embryonic Proteins, Vol. II, p. 151-161 (Lehmann, F. G. ed.) Amsterdam: Elsevier, North-Holland, Biomedical Press.

29. Evrin, P. E. \& Wibell, L. (1972), Scand. J. Clin. Lab. Invest. $29,69-74$.

30. Adami, H. O., Hällgren, R. \& Lundquist, G. (1979), Clin. Chim. Acta 93, 43-49.

31. Coombes, R. C., Powles, T. J., Gazet, J. C., Ford, H. T., Sloane, J. P., Laurence, D. J. R. \& Neville, A. M_(1977), Lancet $I, 132-134$. 
32. Lamerz, R., Leonhardt, A., Ehrhart, H. \& Lieven, H. v. (1979), Carcino-Embryonic Proteins, Vol. II, p. 139-145 (Lehmann, F. G. ed.) Amsterdam: Elsevier, North-Holland Biomedical Press.

33. Myers, R. E., Sutherland, D. J. A., Meakin, J. W., Kellen, J. A., Malkin, D. G. \& Malkin, A. (1978), Cancer 42, $1520-$ 1526.

34. Steward, A. M., Nixon, D., Zamcheck, N. \& Aisenberg, A. (1974), Cancer 33, 1246-1252.

35. Tormey, D. C., Waalkes, T. P., Snyder, J. J. \& Simon, R. M. (1977), Cancer 39, 2397-2402

36. Chu, T. M. \& Nemoto, T. (1973), J. Nat. Cancer Inst. 51, $1119-1122$

37. Myers, R. E., Sutherland, D. J. A., Meakin, J. W., Malkin, D. G., Kellen, J. A. \& Malkin, A. (1979), Carcino-embryonic
Proteins, Vol. II, p. 133-138, (Lehmann, F. G. ed.) Amsterdam: Elsevier, North Holland Biomedical Press.

38. Kult, J., Lämmlein, C., Röckel, A. \& Heidland, A. (1974), Dtsch. Med. Wochenschr. 99, 1686-1688.

39. Wibell, L., Evrin, P. E. \& Berggard, I. (1973), Nephron 10, $320-331$.

40. Nilsson, K., Evrin, P. E., Berggard, I. \& Ponten, J. (1973), Nature New Biol. 244, 44-45.

41. Nilsson, K., Evrin, P. E. \& Welsh, K. I. (1974), Transplant Rev. 21, 53-84.

42. Staab, H. J., Anderer, F. A., Hiesche, K., Wehrle, E. \& Rodatz, W. (1980), Clin. Chim. Acta 106, 309-317.

Hans-Jürgen Staab, F. Alfred Anderer

Friedrich-Miescher-Laboratorium der Max-Planck-Gesellschaft Spemannstraße 37-39

D-7400 Tübingen

\section{Ahlemann}

Medizinisches Strahleninstitut der Universität Tübingen

Röntgenweg 11

D-7400 Tübingen

K. Hiesche, W. Rodatz

Pharmacia Diagnostics AB

Box 17

S-75103 Uppsala 
. 